\title{
Development, biological regulation, and fate of ctenophore blooms in the York River estuary, Chesapeake Bay
}

\author{
Robert H. Condon ${ }^{1,2, *}$, Deborah K. Steinberg ${ }^{1}$ \\ ${ }^{1}$ Virginia Institute of Marine Science, College of William \& Mary, 1208 Greate Rd., Gloucester Point, Virginia 23062, USA \\ ${ }^{2}$ Present address: Bermuda Institute of Ocean Sciences, 17 Biological Lane, Ferry Reach, St George's GE01, Bermuda
}

\begin{abstract}
Blooms of the lobate ctenophore Mnemiopsis leidyi proliferate in estuaries and coastal regions worldwide. However, their role in food web structure and carbon flow between trophic levels is not fully understood. During 2003-2006, we conducted field surveys along a salinity gradient in the lower York River, a sub-estuary of the Chesapeake Bay, to determine factors controlling the timing and magnitude of $M$. leidyi blooms, and to evaluate effects of gelatinous zooplankton on carbon cycling. Samples for density, biovolume, and carbon content of ctenophores, scyphomedusae, and mesozooplankton were collected using surface net tows and quantified in the laboratory. Historical published records on ctenophores and physical data from regional databases were used to complement this dataset. The highest biomass of $M$. leidyi occurred in early summer (up to $50 \mathrm{mg} \mathrm{C} \mathrm{m}{ }^{-3}$ ), although blooms also appeared in winter and spring. Peaks in ctenophore biomass in the mesohaline York River occurred in May, 1 mo earlier than further downriver in the polyhaline mainstem Chesapeake Bay, likely due to higher ctenophore reproductive potential and larval dispersal upriver. Copepod biomass remained low $\left(<10 \mathrm{mg} \mathrm{C} \mathrm{m}^{-3}\right)$ during ctenophore blooms but was not limiting for M. leidyi. Rather, high predation by Chrysaora quinquecirrha scyphomedusae on M. leidyi (scyphomedusae requirements of up to $240 \%$ of $M$. leidyi $\mathrm{C} \mathrm{d}^{-1}$ ) appears to cause the rapid decline in summer ctenophore blooms, and we hypothesize that, subsequently, medusae become carbon-limited. Long-term trends suggest $M$. leidyi blooms have shifted forward 1 mo, possibly due to localized temperature increases over the past $40 \mathrm{yr}$. These results suggest that $M$. leidyi blooms have a pivotal, and potentially transformative, role in carbon transfer in estuarine and coastal food webs.
\end{abstract}

KEY WORDS: Mnemiopsis leidyi - Reproduction · Cydippid larvae · Scyphomedusae predation · Chrysaora quinquecirrha · Carbon cycle · Climate · York River · Chesapeake Bay

\section{INTRODUCTION}

Large increases in gelatinous zooplankton populations have occurred in many coastal and estuarine ecosystems worldwide (e.g. Brodeur et al. 2002, Uye et al. 2003). Given current and projected global increases in eutrophication and overfishing, these trends are likely to continue into the near future with unknown consequences (Mills 2001). The lobate ctenophore Mnemiopsis leidyi is one example of a widespread and invasive species (e.g. Purcell et al. 2001, Faasse \& Bayha 2006) that blooms in estuarine and coastal sys- tems, including Chesapeake Bay and its tributaries (Burrell \& van Engel 1976, Feigenbaum \& Kelly 1984, Purcell et al. 2001, Purcell \& Decker 2005). Although blooms of $M$. leidyi represent one of the most striking seasonal changes in the Chesapeake Bay pelagic community (Purcell \& Decker 2005), the physical and biological mechanisms that regulate ctenophore populations are not fully understood.

The economic impacts of Mnemiopsis leidyi blooms in estuarine and coastal systems are well documented. For example, its accidental introduction into the Black Sea and subsequent expansion has significantly 
altered food web structure and heavily impacted commercial fisheries because $M$. leidyi are voracious predators on copepods and ichthyoplankton (Purcell \& Decker 2005, Costello et al. 2006). Similar impacts have been observed in native habitats, where temporal shifts in M. leidyi blooms have occurred and consequently driven Acartia copepod populations to summer extinction (Sullivan et al. 2001). Despite obvious predatory impacts on food web structure, we know very little regarding what impact $M$. leidyi has on largescale ecosystem processes, such as carbon cycling.

Several studies have evaluated the seasonality, environmental cues, and biological characteristics that control Mnemiopsis leidyi populations, and demonstrate that ctenophores are well adapted to bloom formation. Mnemiopsis ctenophores are hermaphrodites that have the ability to produce high numbers of cydippid larvae via broadcast spawning (>1500 larvae $\left.\mathrm{m}^{-3}\right)$, but reproductive effort is restricted to temperatures $>10$ to $15^{\circ} \mathrm{C}$ (Purcell et al. 2001, Costello et al. 2006). As a result, a major increase in ctenophore density in the Chesapeake Bay region occurs in late spring (Purcell et al. 2001), when water temperatures increase, thereby releasing thermal limitation on reproduction and growth (Costello et al. 2006). Ctenophore biomass may further accumulate at these times because ctenophores have wide salinity tolerance (i.e. they are euryhaline), copepod prey are generally abundant, and reproductive output can occur multiple times (Purcell \& Decker 2005), and ctenophore growth rates are high (Reeve et al. 1989).

The persistence of Mnemiopsis leidyi blooms is temporally and spatially dependent on various physical and biological variables. The cannibal ctenophore Beroë sp. and the scyphomedusan Chrysaora quinquecirrha can consume large quantities of M. leidyi (Purcell \& Cowan 1995, Finenko et al. 2003), and, in Chesapeake Bay, declines in ctenophore biomass have been attributed to predation by these gelatinous carnivores (Burrell \& van Engel 1976, Feigenbaum \& Kelly 1984, Purcell et al. 2001, Purcell \& Decker 2005). Other scyphomedusae are found in Chesapeake Bay, including Aurelia sp. and Cyanea sp., and these predators may also contribute to ctenophore depletion (Purcell \& Decker 2005). Several fish and turtle species also consume ctenophores (Link \& Ford 2006), but while some vertebrate species are abundant in Chesapeake Bay, they do not consume gelatinous zooplankton (Murdy et al. 1997, D. Portnoy pers. comm.). Low dissolved oxygen concentrations can have pronounced effects on crustacean zooplankton populations, but $M$. leidyi tolerate hypoxia (Decker et al. 2004). Food limitation (e.g. starvation) and physical advection (e.g. currents) may also play important roles in the removal of ctenophore biomass from estuarine and coastal waters (Burrell \& van Engel 1976, Feigenbaum \& Kelly 1984, Purcell et al. 1994, Costello et al. 2006, J. Costello pers. comm.).

We report results from a multi-year field program in the lower York River with the objective of determining the major physical and biological factors controlling the timing, accumulation, and decline of Mnemiopsis leidyi populations. Previous research on M. leidyi blooms in this estuary identified seasonality and regions where blooms proliferated (Burrell \& van Engel 1976). Because temporal shifts in M. leidyi blooms have been observed in other regions (Sullivan et al. 2001, Costello et al. 2006), we evaluated whether similar shifts have occurred in the Chesapeake Bay. In addition, we determine particulate organic carbon (POC) transfers within the local food web in order to evaluate the potential impact of gelatinous zooplankton blooms on carbon cycling within estuarine ecosystems.

\section{MATERIALS AND METHODS}

Sampling location. The York River estuary is a partially-mixed, microtidal, sub-estuary of Chesapeake Bay (Lin \& Kuo 2001), approximately $35 \mathrm{~km}$ from the mouth of the Bay (Fig. 1). The York River extends

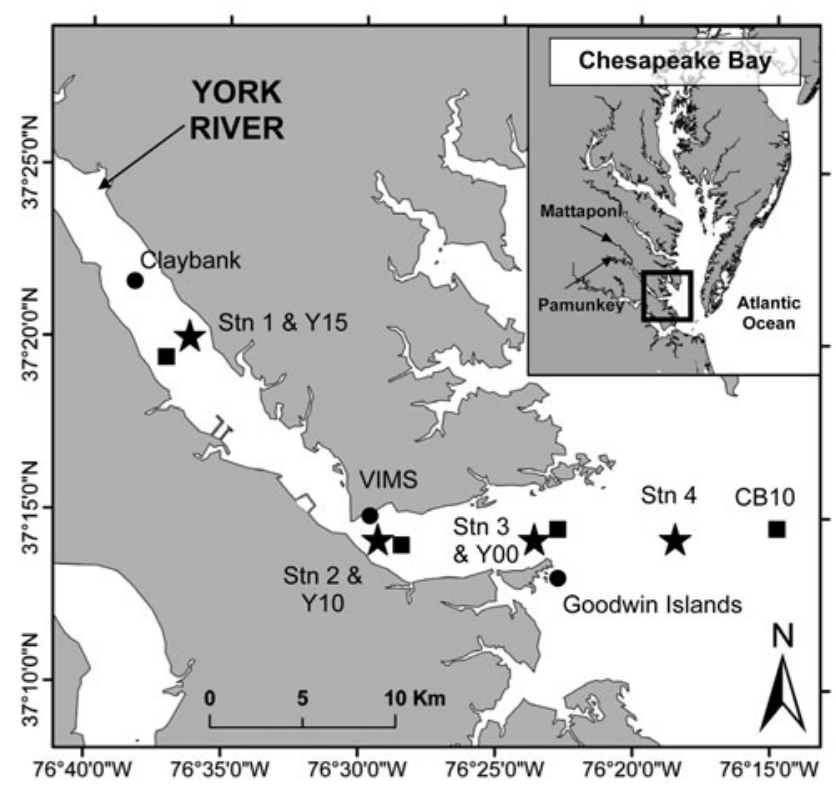

Fig. 1. Stations sampled in current ( $\star$ ) and historical ( $\square$ ) studies, and other monitoring sites $(\bullet)$ in the York River estuary. Y15, Y10, Y00, and CB10 denote historical monitoring sites from Burrell (1972). Chesapeake Bay National Estuarine Research Reserve System Virginia monitoring stations are located at Claybank (YRK 015.09), Virginia Institute of Marine Science (VIMS, YRK 005.40), and Goodwin Islands (CHE 019.38). Inset: USGS monitoring stations located in the Pamunkey (Site 01673000) and Mattaponi (Site 01674500) Rivers 
about $55 \mathrm{~km}$ in length from its formation at the confluence of the Pamunkey and Mattaponi Rivers to the mouth. We sampled 4 stations along a $15 \mathrm{~km}$ transect in the lower York River (Fig. 1). Sampling sites ranged along a salinity gradient from midway upriver (Stn 1) to the southwestern flank of the Bay about $3 \mathrm{~km}$ outside the mouth of the York River (Stn 4). Stations were determined based on proximity to ongoing and historical research programs monitoring gelatinous zooplankton and physical parameters within the York River estuary and Chesapeake Bay. Sampling usually occurred twice a month between May and August, and monthly between September and April, with daily sampling completed within 3 to $4 \mathrm{~h}$.

Zooplankton sampling. A variety of biological and physical parameters were measured at each of the stations on each sampling date. All gelatinous zooplankton species were collected by replicate, double oblique tows in the surface waters ( 0 to $3 \mathrm{~m}$ ) using $1 \mathrm{~m}$ diameter plankton nets with a non-filtering cod end and attached flowmeter. After collection, zooplankton net samples were gently emptied into buckets filled with ambient York River water, stored at in situ temperature, and transported to VIMS for enumeration in the laboratory. When tows contained high gelatinous biomass ( $>21$ by volume biomass in tow), samples were counted in the field.

A range of morphometric measurements were made on live gelatinous zooplankton in the laboratory. Each sample was poured through $500 \mu \mathrm{m}$ mesh sieves that retained ctenophores and medusae. Ctenophores and medusae were gently separated by species, counted, and total displacement biovolumes measured according to Purcell \& Decker (2005). In tows containing $>50$ Mnemiopsis leidyi individuals, subsamples were taken and scaled up to total density and biovolume. Total density $\left(D\right.$, no. $\left.\mathrm{m}^{-3}\right)$ and biovolume $\left(B, \mathrm{ml} \mathrm{m}^{-3}\right)$ of ctenophores and medusae were standardized using volume filtered by the net.

Ctenophore total length (TL, mm) and medusae bell diameter $(\mathrm{BD}, \mathrm{mm})$ were measured on up to 30 randomly selected individuals from each tow. Additional biomass measurements were made on individual ctenophores and medusae over their full size range collected at each station. Individual displacement biovolumes $(\mathrm{ml})$ were measured in graduated cylinders, and weights determined on a high precision balance. For dry weights (DW), individuals were oven dried at $55^{\circ} \mathrm{C}$ for 1 to $2 \mathrm{wk}$ until weights between 2 successive days were $\pm 0.1 \%$ (mg). Linear regressions plotting individual size and biomass were derived (Table 1) and used in calculations of total ctenophore and medusae biomass in the field and of clearance rates (see below).

Ctenophores and medusae were collected in nets of 2 different mesh sizes: $500 \mu \mathrm{m}$ (June 2003-May 2004) and $200 \mu \mathrm{m}$ (July 2004-May 2005). To determine whether there were differences in catching efficiency between nets, we performed replicate tows $(n=2)$

Table 1. Mnemiopsis leidyi and Chrysaora quinquecirrha. Linear regressions calculated from size and biomass measurements of individuals collected in net tows. All linear regressions were significant $(\mathrm{p}<0.0001)$ and presented in the form in which they were applied to data in this study. WW = wet weight $(\mathrm{g})$ of $M$. leidyi $(M l)$; TB = tentacle bulb length $(\mathrm{mm})$; $\mathrm{TL}=M$. leidyi total length $(\mathrm{mm}) ; \mathrm{CR}_{C q M l}=$ clearance rates for $C$. quinquecirrha $(C q)$ consuming $M$. leidyi $\left(l_{\text {medusa }}{ }^{-1} \mathrm{~d}^{-1}\right) ; \mathrm{BD}=C$. quinquecirrha bell diameter $(\mathrm{mm}) ; D_{A C}=$ copepod density $\left(\right.$ no. $\left.\mathrm{l}^{-1}\right) ; \mathrm{CR}_{M I A C}=$ clearance rate for $M$. leidyi consuming copepods $(A C)\left(1 \mathrm{ctenophore}^{-1} \mathrm{~d}^{-1}\right)$; $\mathrm{CI}_{C q A C}=$ ingestion rate for $C$. quinquecirrha consuming copepods (no. copepods medusa $\left.{ }^{-1} \mathrm{~d}^{-1}\right) ; T=$ temperature $\left({ }^{\circ} \mathrm{C}\right) ; C_{M l}=$ total organic carbon of $M$. leidyi $(\mathrm{mg}) ; \mathrm{POC}=$ particulate organic carbon $(\mathrm{mg}) ; \mathrm{DW}=$ dry weight $(\mathrm{g}) ;$ na $=$ not available

\begin{tabular}{|c|c|c|c|c|c|}
\hline Eq. & Linear regression & $r^{2}$ & $\mathrm{n}$ & Utilization of equation & Source \\
\hline 1 & $\mathrm{WW}_{M l}=0.81 \mathrm{~TB}_{M l}^{1.913}$ & 0.98 & 67 & $\begin{array}{l}\text { Wet weight as a function of tentacle } \\
\text { bulb length }\end{array}$ & Purcell (1988) \\
\hline 2 & $\mathrm{TL}_{M l}^{0.5}=3.774 \mathrm{WW}_{M l}{ }^{0.25}+0.996$ & 0.93 & 660 & Total length as a function of wet weight & This study \\
\hline 3 & $\mathrm{POC}_{\mathrm{Stn} 1}=80.2 \mathrm{Chl} a+1517$ & 0.52 & 39 & C:chl a conversions for upriver at Stn 1 & This study \\
\hline 4 & $\begin{array}{l}\log \mathrm{CR}_{C q M l}=2.026 \log \mathrm{BD}_{C q} \\
-0.756\end{array}$ & 0.93 & na & $\begin{array}{l}\text { C. quinquecirrha clearance rates } \\
\text { on } M \text {. leidyi }\end{array}$ & Purcell \& Cowan (1995) \\
\hline 5 & $\mathrm{CR}_{M I A C}=11.22 \mathrm{WW}_{M I}^{0.5413}$ & na & na & M. leidyi clearance rates on copepods & Purcell et al. (2001) \\
\hline 6 & $\begin{array}{l}\log \mathrm{CI}_{C q A C}=0.85 \log \mathrm{BD}_{C q}+ \\
1.43 \log D_{A C}+3.96 \log T-6.43\end{array}$ & na & 240 & $\begin{array}{l}\text { C. quinquecirrha ingestion rates } \\
\text { on copepods }\end{array}$ & Purcell (1992) \\
\hline 7 & $\mathrm{DW}_{M l}^{0.25}=0.101 \mathrm{TL}_{M l}^{0.5}-0.111$ & 0.85 & 617 & Dry weight as a function of total length & This study \\
\hline 8 & $C_{M l}{ }^{0.25}=300 \mathrm{DW}_{M l}{ }^{0.25}+0.127$ & 0.92 & 91 & $\begin{array}{l}\text { Carbon content as a function of dry } \\
\text { weight for } M \text {. leidyi }\end{array}$ & This study \\
\hline 9 & $\mathrm{BD}_{C q}=63.291 \mathrm{DW}_{C q}{ }^{0.5}+19.367$ & 0.82 & 43 & $\begin{array}{l}\text { Carbon content as a function of dry } \\
\text { weight for C. quinquecirrha }\end{array}$ & This study \\
\hline
\end{tabular}


using both net types at each station after May 2005. There was no significant difference in volume-specific biovolumes $(F=0.53, \mathrm{p}=0.71)$ and densities $(F=0.34$, $\mathrm{p}=0.85$ ) of Mnemiopsis leidyi collected in the $200 \mu \mathrm{m}$ and $500 \mu \mathrm{m}$ nets (fully nested ANOVA with station, net, and date as factors). Supplemental tows using $1600 \mu \mathrm{m}$ mesh nets were conducted between May and August 2005 and 2006 to collect large scyphomedusae.

Mesozooplankton (>200 $\mu \mathrm{m}$ ) and Mnemiopsis leidyi larvae were sampled from surface waters (0 to $2 \mathrm{~m}$ ) at each station during 2004-2006 using a 0.5 m diameter net (200 $\mathrm{mm}$ mesh) equipped with a flowmeter and a non-filtering cod end; data for Stns 1 and 4 are reported here. Following collection, samples were concentrated on a $53 \mu \mathrm{m}$ mesh sieve and immediately fixed in $4 \%$ formaldehyde buffered with sodium borate. Subsamples were taken using the Stempel pipette method and at least 200 non-gelatinous organisms were counted under a dissecting microscope (100× magnification). Zooplankton were classified to major taxa and abundant copepod species noted. Total M. leidyi larvae in preserved samples were determined by counting tentacle bulbs (Purcell 1988). Larval growth stage was verified by first converting bulb length $(\mathrm{TB}, \mathrm{mm})$ to $M$. leidyi wet weight $\left(\mathrm{WW}_{M 1}, \mathrm{~g}\right)$, using Eq. (1) (Table 1), and then to M. leidyi TL (mm, Eq. 2, Table 1). M. leidyi individuals $>10 \mathrm{~mm}$ (lobed) were omitted from calculations of larval density.

York River physical properties. We analyzed data on temperature, salinity and dissolved oxygen collected by the Chesapeake Bay National Estuarine Research Reserve System Virginia (CBNERRSVA, www2.vims.edu/ vecos/) using monitoring stations located at Goodwin Islands (CHE 019.38), Gloucester Point/VIMS (YRK 005.40) and Claybank (YRK 015.09) (Fig. 1). Supplemental temperature data were obtained from the Virginia Institute of Marine Science (VIMS) Ferry Pier (www.vims.edu/resources/databases.html) and VIMS buoy (www.vims.edu/ lbrass/vims_obs.html) monitoring sites. Total freshwater input into the York River from January-June was calculated from average daily freshwater inputs $\left(\mathrm{m}^{3} \mathrm{~s}^{-1}\right)$ obtained from United States Geological Survey (USGS) monitoring stations located in the Pamunkey (Site 01673000) and Mattaponi (Site 01674500) Rivers (http://water.usgs.gov/osw/).

Historical trends in ctenophores. We obtained historical data on Mnemiopsis leidyi blooms in the York River by conducting a literature and database search for sampling conducted in southern Chesapeake Bay and the York River. We only considered data that were acquired at or in the vicinity of our sampling sites and dates (Fig. 1). As ctenophore physiology and reproduction are sensitive to temperature (Purcell et al. 2001), we compared timing of ctenophore blooms to devia- tions from average daily temperatures recorded from 1955-2006 at the VIMS Ferry Pier using Hsieh (1979), and VIMS and CBNERRSVA databases. In addition, long-term trends in Pamunkey and Mattaponi River freshwater inputs were analyzed, and used as a proxy for salinity.

POC biomass in zooplankton and phytoplankton standing stocks. Total $\mathrm{C}$ in ctenophore, scyphomedusae, and calanoid copepod populations $\left(\mathrm{mg} \mathrm{C} \mathrm{m}^{-3}\right)$ was calculated by multiplying field measurements of biomass ( $\mathrm{mg} \mathrm{DW} \mathrm{m}^{-3}$ ) with values of weight-specific $\mathrm{C}$ content $\left(\mathrm{mgC} \mathrm{g} \mathrm{DW}^{-1}\right)$. POC content of pre-weighed subsamples of ground, dried Mnemiopsis leidyi was measured on a Carlo Erbra EA-1108 CHN Elemental Analyzer. C biomass for Chrysaora quinquecirrha was calculated using a conversion factor of $0.111 \mathrm{mg} \mathrm{C} \mathrm{mg}$ $\mathrm{DW}^{-1}$ (Nemazie et al. 1993) after converting medusa size to dry biomass using empirical relationships (see 'Results'). Total copepod C biomass was calculated by multiplying copepod densities by an individual weight of $6 \mu \mathrm{g}$ C for Acartia tonsa (Roman 1977).

At each station, surface water ( 0 to $2 \mathrm{~m}$ ) was collected in $1 \mathrm{l}$ polycarbonate bottles for determination of chlorophyll a (chl a) and total suspended POC concentrations. Chl $a$ and total suspended POC were measured using particulates retained on pre-combusted Whatman GF-F filters. POC samples were dried at $55^{\circ} \mathrm{C}$ and desiccated with $6 \mathrm{~N} \mathrm{HCl}$ prior to measurement. Average C:chl a was determined using slopes of linear plots regressing chl a against total POC (Eq. 3, Table 1). Total phytoplankton POC was determined by multiplying chl a by estimated C:chl a.

Chrysaora and Mnemiopsis predation. We determined ingestion rates by gelatinous zooplankton on copepods, and by Chrysaora quinquecirrha on Mnemiopsis leidyi (Purcell \& Cowan 1995, Purcell \& Decker $2005)$ to evaluate effects of food limitation and predation, respectively, on $M$. leidyi populations during April-August. Calculations of population ingestion rates were based on $\mathrm{C}$ biomass of standing stocks, published empirical relationships linking predator and prey type, and mean size of Mnemiopsis and Chrysaora on each sample date.

Chrysaora clearance rates on Mnemiopsis ( $\mathrm{CR}_{\text {CqMl }}$ ) were calculated using the regression (Eq. 4, Table 1) relating $C$. quinquecirrha medusa size $\left(\mathrm{BD}_{C q}, \mathrm{~mm}\right)$ to M. leidyi cleared (Purcell \& Decker 2005). $\mathrm{CR}_{\text {CqMl }}$ $\left(1\right.$ medusa $^{-1} \mathrm{~d}^{-1}$ ) were converted to $\mathrm{C}$ ingested by Chrysaora populations $\left(I_{C q M l}, \mathrm{mg} \mathrm{C} \mathrm{m}^{-3} \mathrm{~d}^{-1}\right)$ as follows:

$$
I_{C q M l}=\mathrm{CR}_{C q M l} \times C_{M l} \times D_{C q}
$$

where $C_{M l}$ is $M$. leidyi C biomass $\left(\mathrm{mg} \mathrm{C}^{-1}\right)$ and $D_{C q}$ is C. quinquecirrha density (medusae $\mathrm{m}^{-3}$ ).

Mnemiopsis size was converted to wet biomass using Eq. (2) (Table 1), and clearance rates on copepods 
$\left(\mathrm{CR}_{\text {MlAC }}\right)$ were determined using Eq. (5) (Table 1). Clearance rates $\left(1\right.$ medusa $^{-1} \mathrm{~d}^{-1}$ ) were converted to potential copepod $\mathrm{C}$ ingested by $M$. leidyi populations $\left(I_{M l A C}, \mathrm{mg} \mathrm{C} \mathrm{m}^{-3} \mathrm{~d}^{-1}\right)$ as follows:

$$
I_{M l A C}=\mathrm{CR}_{M l A C} \times C_{A C} \times D_{M I}
$$

where $C_{A C}$ is calanoid copepod $\mathrm{C}$ biomass $\left(\mathrm{mg} \mathrm{C}^{-1}\right)$ and $D_{M l}$ is $M$. leidyi density (ctenophores $\mathrm{m}^{-3}$ ).

Chrysaora ingestion rates on copepods (mostly Acartia) were calculated using Eq. (6) (copepods medusa $^{-1} \mathrm{~d}^{-1}$, Table 1) (Purcell 1992), and converted to copepod $\mathrm{C}$ ingested $\left(\mathrm{CI}_{C q A C}\right.$ mg copepod $\mathrm{C}$ medusa ${ }^{-1}$ $\mathrm{d}^{-1}$ ) by multiplying by $6 \mu \mathrm{g} C$ copepod $^{-1}$ (Roman 1977). Chrysaora population $\mathrm{C}$ ingestion rates on copepods $\left(I_{C q A c}, \mathrm{mgC} \mathrm{m}^{-3} \mathrm{~d}^{-1}\right)$ were determined by multiplying $\mathrm{CI}_{C q A C}$ by $C$. quinquecirrha density.

To assess the potential for predator C-limitation and predation on gelatinous zooplankton, population $\mathrm{C}$ ingestion rates were converted to $\mathrm{C}$-based daily prey consumption (DC, no. prey $\mathrm{m}^{-3} \mathrm{~d}^{-1}$ ) for Mnemiopsis leidyi and Chrysaora quinquecirrha by dividing the population ingestion rate $(I)$ for each predator by the aver-
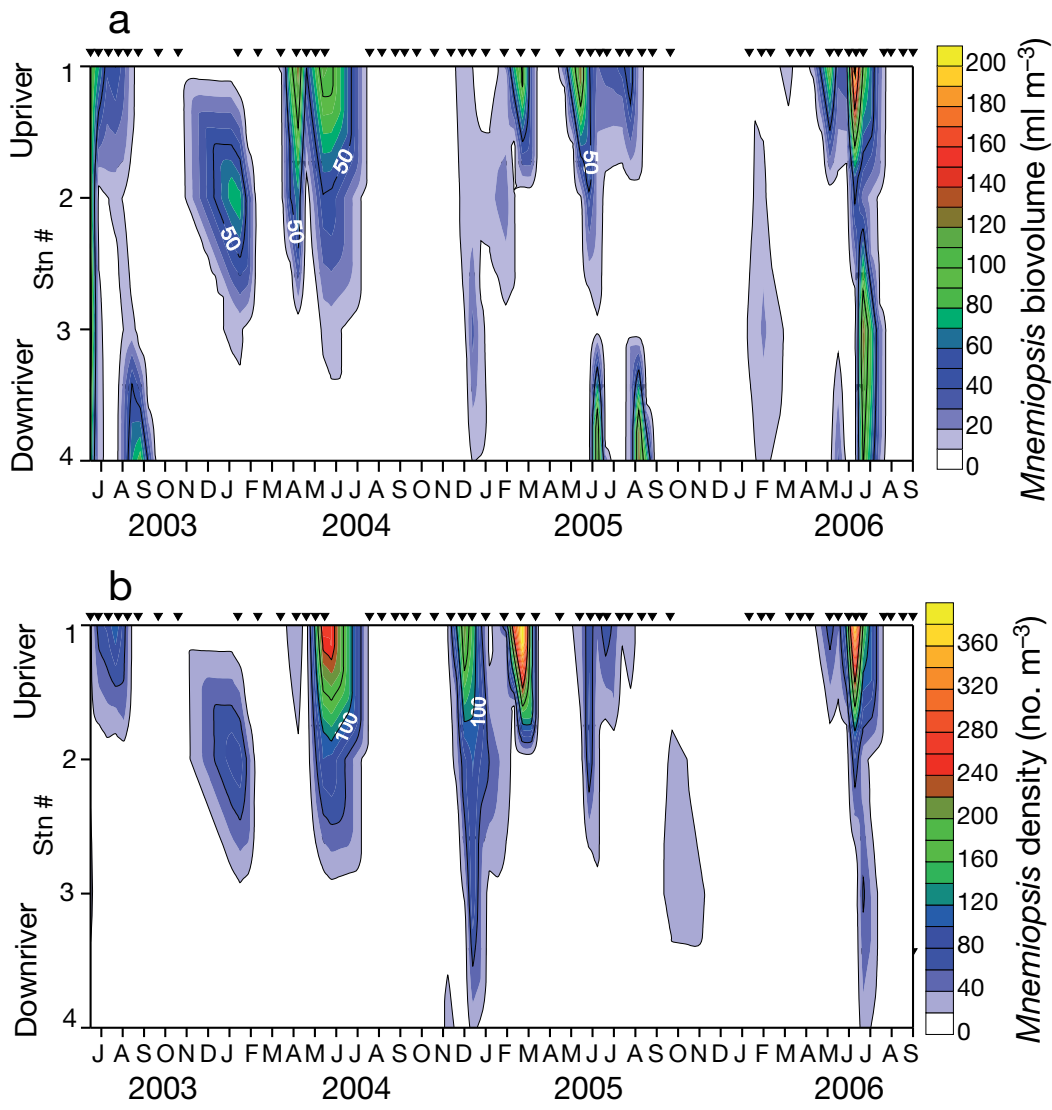

Fig. 2. Mnemiopsis leidyi. Contour plots of average (a) M. leidyi biomass (biovolume, $\mathrm{ml}$ ctenophore $\mathrm{m}^{-3}$ ) and (b) density (no. ctenophores $\mathrm{m}^{-3}$ ) for all 4 stations (plotted up- to downriver) sampled in the York River estuary. Plots generated with Surfer $^{\odot}$ software using triangulation data interpolation. v: sample dates age $\mathrm{C}$ biomass for each prey (ctenophores or copepods, $\mathrm{mgC}$ ind. $^{-1}$ ). Daily population predation pressure (DPP, \% ingested $\mathrm{d}^{-1}$ ) for each gelatinous predator was determined by dividing DC by prey density (no. prey $\mathrm{m}^{-3}$ ) and multiplying by $100 \%$.

Statistical analyses. Data were analyzed using ANOVA, 2-sample $t$-tests, and linear regressions using Minitab statistical software. Data were checked for normality and homogeneity of variance primarily using box plots and histograms of data and residuals. Where data did not conform to the assumptions of the statistical test, data were either $\log _{10}$, or square- or 4 th-root transformed following Quinn \& Keough (2002). We assumed a level of significance of $\alpha=0.05$.

\section{RESULTS}

\section{Seasonal periodicity of Mnemiopsis blooms}

During this study, Mnemiopsis leidyi was the most common gelatinous species in surface waters throughout the lower York River estuary. The seasonal cycle of $M$. leidyi was bi-modal, with high biomass and density peaks observed during mid-winter (December-February) and early summer (May-June) (Figs. 2 \& 3). The only exception to this pattern is the lack of high biomass in winter 2005-2006. Time periods of high $M$. leidyi biomass were relatively brief, persisting for 2 to 4 wk (Figs. 2 \& $3 a-d)$.

Major differences were observed between the 4 stations in Mnemiopsis leidyi biomass, density, and timing of the springsummer bloom. The highest $M$. leidyi biomass and density consistently occurred upriver at Stn 1 (Figs. 2 \& 3a,c), and occasionally at Stn 2 (biomass: $F=9.85, \mathrm{p}<0.0001$, density: $F=18.25, \mathrm{p}<0.0001 ; 2$-way ANOVA with station and year as fixed variables) (Fig. 2). At these sites, M. leidyi biomass peaks first appeared in May with some secondary peaks in June and July (Figs. 2 \& 3a,c). May biomass (97-135 ml $\mathrm{m}^{-3}$ ) was consistent between years (20042006, $F=3.08, p=0.072$ ) but higher densities were recorded in 2004 (221.5 \pm 67.6, $F=6.15, \mathrm{p}=0.010$ ) than in 2005-2006 at Stn 1 (Fig. 3a). Compared to Stn 1, the timing of spring-summer biomass peaks in the polyhaline region (Stns 3 and 4) was offset by a month, with annual peaks occurring in June (Fig. 3b,d). High biomass peaks were not observed in May at the downriver sites 

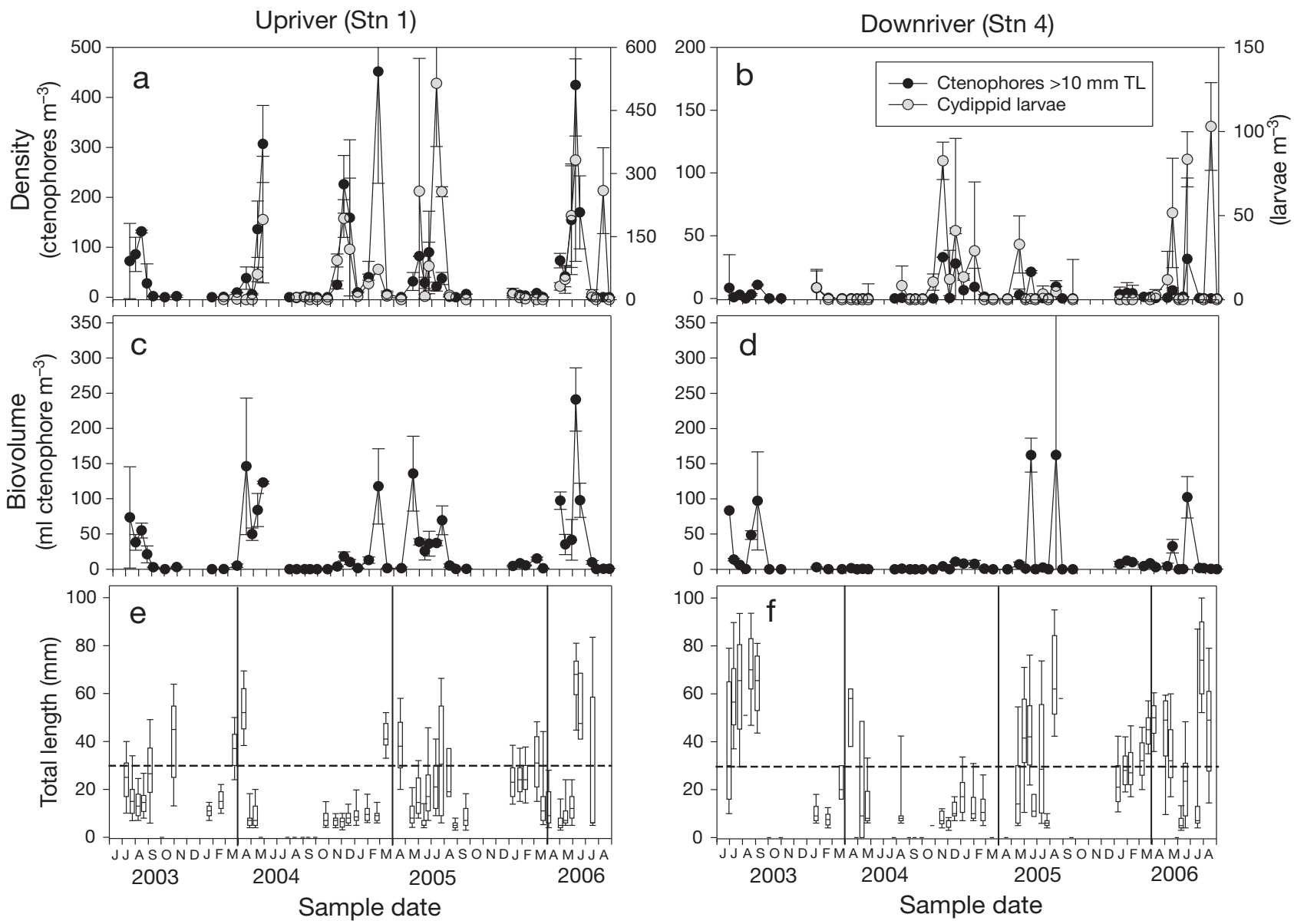

Fig. 3. Mnemiopsis leidyi. Comparison of population and individual size of M. leidyi blooms between Stns 1 and 4 . (a,b) Mean $( \pm 1 \mathrm{SD})$ density (ctenophores $\mathrm{m}^{-3}$ ) of lobed $(>10 \mathrm{~mm}$ total length, TL) and cydippid larval $M$. leidyi. Note difference in density scales ( $y$-axes). (c,d) Mean ( $\pm 1 \mathrm{SD}$ ) biomass (biovolume, $\mathrm{ml}$ ctenophore $\mathrm{m}^{-3}$ ) of lobed $M$. leidyi. (e,f) M. leidyi size range (mm). (- - ): minimum size for mature ctenophores $(30 \mathrm{~mm}$ TL). Box and whiskers represent 10th, 25th, median, 75th and 90th percentiles

(Fig. 3b,d). We focus the remainder of our analyses primarily on the 2 distinct end-member stations (Stns 1 and 4).

\section{Potential biological and physical controls on Mnemiopsis leidyi blooms}

Reproduction potential and larval production

The potential for mature ctenophores to seed high ctenophore densities through egg and larval production was higher at Stn 1 due to higher biomass and density of mature ctenophores (Fig. 3). The size distribution of Mnemiopsis leidyi differed with month between the 2 sites (Fig. 3e,f). Preceding summer peaks (April 2004-2005, no data for Stn 1 in April 2006), M. leidyi sizes were larger upriver at $\operatorname{Stn} 1(F=$ 7.37, $p=0.008$, Fig. 3e), where they also occurred at higher density ( $F=27.3, \mathrm{p}=0.002$, Fig. 3a) and biomass $(F=35.8, \mathrm{p}=0.001$, Fig. $3 \mathrm{c})$. In contrast, during summer maximum abundances (May and June), mean ctenophore size was larger at Stn 4 compared to Stn 1 (Fig. 3e,f), except in May 2005 when M. leidyi were rare downriver $(F=174.4, \mathrm{p}<0.0001$, Fig. 3a,c). However, biovolume and density of total (Fig. $3 \mathrm{a}, \mathrm{C}$ ) and $>30 \mathrm{~mm}$ sized ctenophores were higher upriver in all years, so the potential for greater egg production would have likely remained high at this site during May and June (May: $F=55.5, \mathrm{p}<0.0001$, June: $F=$ 7.13, $\mathrm{p}=0.011$ ). Time-averaged May biovolumes upriver were significantly higher than June biovolumes downriver in $2005(F=4.95, \mathrm{p}<0.05)$ and $2006(F=$ $4.89, \mathrm{p}<0.05)$. No comparisons were made for 2004 because no sampling was conducted during June.

In all years surveyed, the highest density of cydippid larvae (ctenophores $<10 \mathrm{~mm}$ ) occurred upriver at Stn 1 $(F=12.7, \mathrm{p}=0.001$, Fig. 3a). Here, large peaks in larval 
density were observed during and after maximum biovolume peaks in adults in both summer and nonsummer periods (Fig. 3a). In contrast, larval density peaks at Stn 4 preceded Mnemiopsis leidyi maximum biovolume peaks (e.g. peaks in larvae May 2005 \& 2006, Fig. 3b), and larval density was significantly related to bloom size (linear regression, $\mathrm{r}^{2}=0.33, t=$ 4.48, $\mathrm{p}<0.0001)$.

\section{Distribution of potential prey}

The most common mesozooplankton sampled were calanoid copepods (primarily Acartia tonsa), cladocerans (Podon sp.) and barnacle nauplii. Copepod density was higher downriver at Stn 4, with annual peaks (>5000 copepods $\mathrm{m}^{-3}$ ) comprised mostly of Acartia between June and September (Fig. 4a), but also in December 2004. In contrast, calanoid copepod density remained low $\left(<1000\right.$ copepods $\left.\mathrm{m}^{-3}\right)$ at $\mathrm{Stn} 1$, except in August 2004 and 2006 where peaks of Eurytemora affinis occurred (Fig. 4a). Total calanoid copepod densities were significantly inversely related to Mnemiopsis leidyi biomass (data combined from Stns 1 and 4, linear regression on $\log _{10}$ transformed data, $\mathrm{r}^{2}=0.34, F=$ 37.9, p < 0.0001) (Fig. 4b). High densities of cladocerans (up to $10201 \pm 554 \mathrm{~m}^{-3}$ ) were also observed during winter 2004 and spring 2005 and 2006.

\section{Predation by large scyphomedusae and Beroë on Mnemiopsis leidyi populations}

Four potential gelatinous consumers of Mnemiopsis leidyi occurred in the York River (Fig. 5). In June and July, relatively large (50 to $150 \mathrm{~mm}$ bell diameter) Chrysaora quinquecirrha scyphomedusae occurred at Stns 1 and 2 in all years, and were mostly absent from Stns 3 and 4, except in 2006 (Fig. 5). Peaks in C. quinquecirrha were associated with water temperatures $>25^{\circ} \mathrm{C}$ and were restricted to salinities ranging from 12 to $20 \mathrm{psu}$. In 2006, large Aurelia scyphomedusae (50 to $320 \mathrm{~mm}$ ) occurred at all stations during June and July (Fig. 5), and large aggregations of Aurelia were observed in the region of Stns 2 and 3 during this time (not sampled). Cannibal ctenophores, Beroë sp., were present during July-August in some years, and in winter 2004 (Fig. 5). In general, Mnemiopsis populations were depleted when scyphomedusae and Beroë populations increased (Fig. 5). In 2006, Cyanea sp. scyphomedusae occurred in high numbers throughout the York River during January-May (Fig. 5). High densities of M. leidyi did not occur when Cyanea was present, but occurred in 2004 and 2005 when Cyanea was absent or at low levels (Figs. 3a-d \& 5).

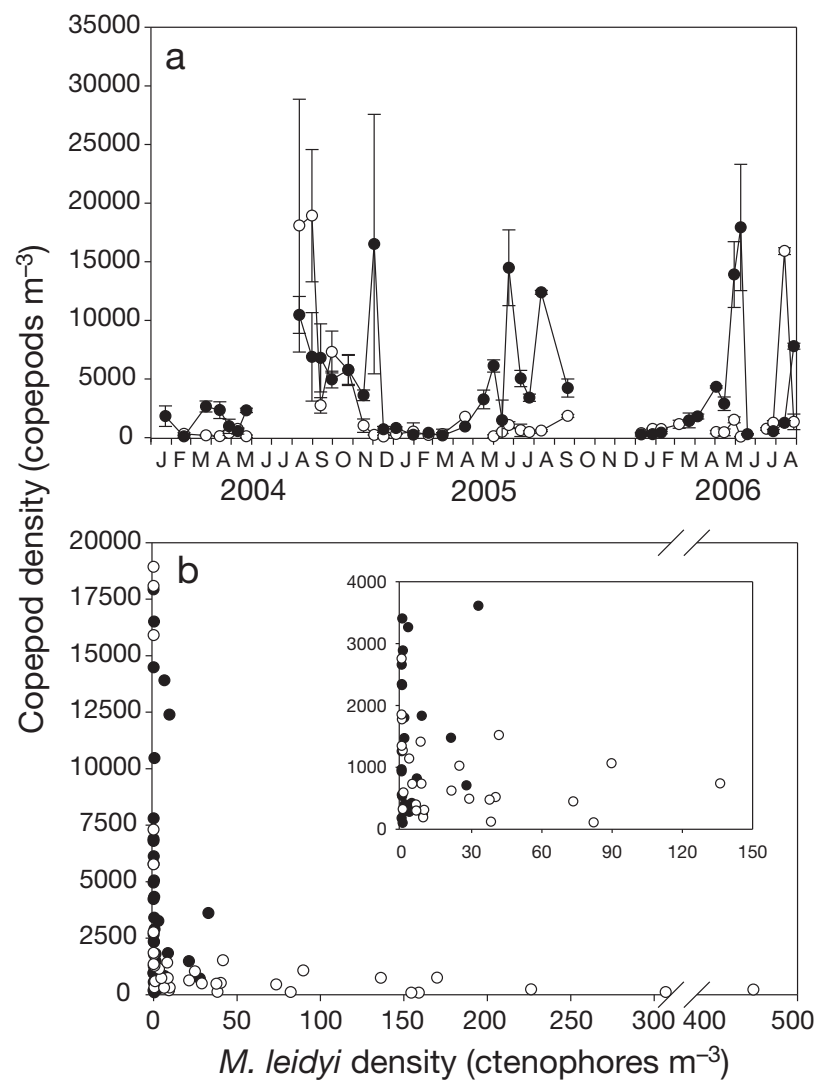

Fig. 4. (a) Mean $( \pm 1$ SD) density of calanoid copepods at Stn 1 (o) and Stn 4 (•). (b) Comparison of mean calanoid copepod and Mnemiopsis leidyi density at Stns 1 and 4. Inset is a blow-up of lower values. Error bars are omitted

Hydrological effects on Mnemiopsis leidyi summer biovolume and density peaks

Throughout the year, maximum abundances of Mnemiopsis leidyi were observed over wide salinity (10 to $22 \mathrm{psu}$ ) and temperature $\left(2\right.$ to $\left.29^{\circ} \mathrm{C}\right)$ ranges, and during the summer at salinities 12 to $21 \mathrm{psu}$ and at temperatures $>17^{\circ} \mathrm{C}$. Salinity differed between Stns 1 and 4 during April-July, with higher salinity recorded at Stn 4 (>20 psu) compared to Stn 1 (12 to $18 \mathrm{psu}, F=$ $13.81, \mathrm{p}<0.0001$ with station, year, and month as fixed variables). There was no significant difference in monthly temperature (April-July) between stations $(F=2.48, \mathrm{p}=0.116)$, and water temperatures were $>17^{\circ} \mathrm{C}$ by May in all years sampled. Spring-summer salinity and temperature were within the range found for ctenophore bloom formation (Purcell \& Decker 2005).

Total monthly average daily freshwater discharge during January-June was similar to the $50 \mathrm{yr}$ mean $\left(7415 \pm 576 \mathrm{~m}^{3} \mathrm{~s}^{-1}\right)$ in 2004 and 2005 (6053 and $7000 \mathrm{~m}^{3}$ $\mathrm{s}^{-1}$, respectively) but lower in $2006\left(3876 \mathrm{~m}^{3} \mathrm{~s}^{-1}\right)$. Low 

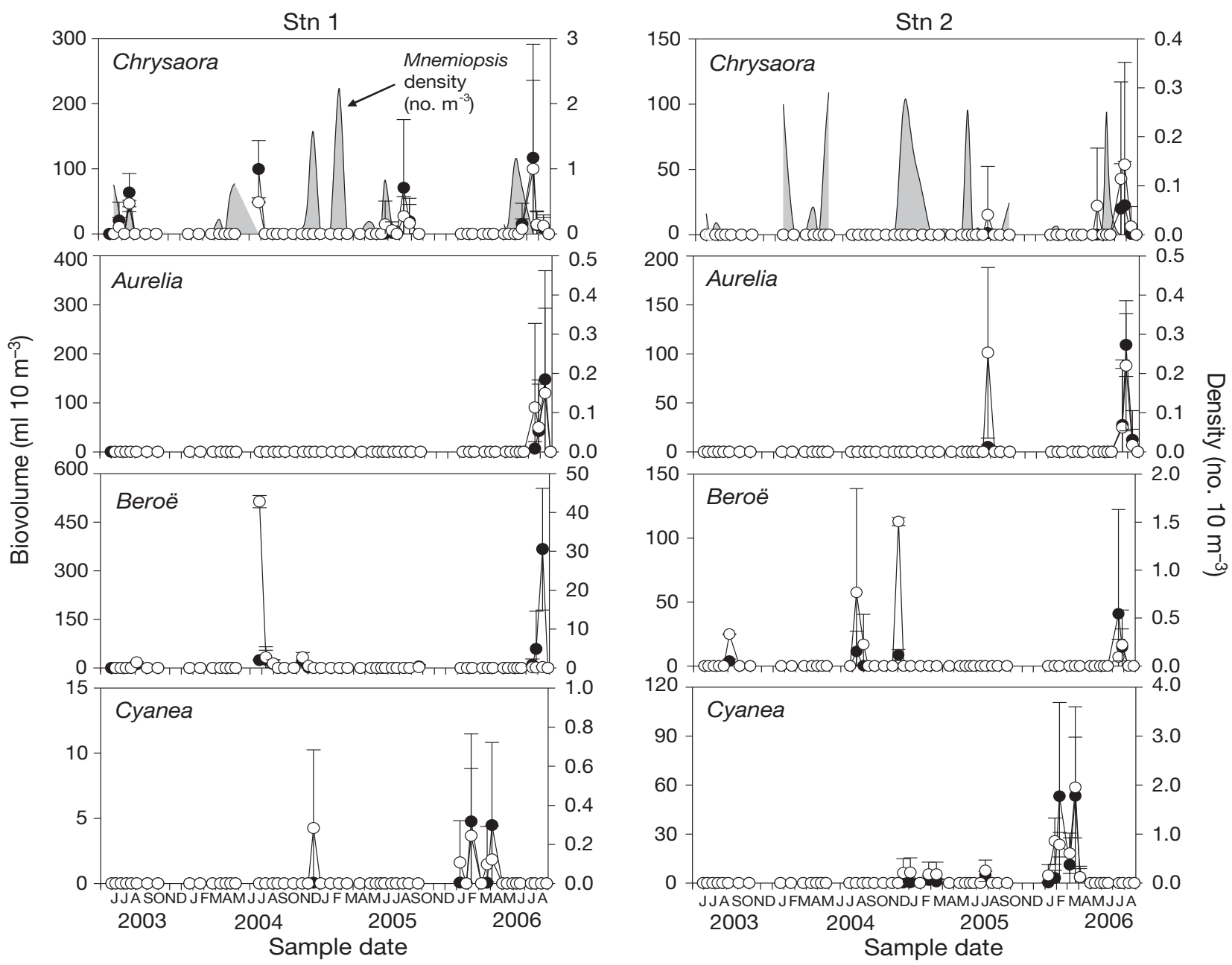

Fig. 5. (This and facing page). Mean $( \pm 1 \mathrm{SD})$ biomass $\left(\mathrm{ml} 10 \mathrm{~m}^{-3}, \bullet\right)$ and density $\left(\right.$ no. $10 \mathrm{~m}^{-3}$, o) of Chrysaora quinquecirrha, Aurelia sp., Beroë sp., and Cyanea sp. up- (Stns 1 and 2) and downriver (Stns 3 and 4). Grey shaded areas represent mean Mnemiopsis leidyi densities (ctenophores $\mathrm{m}^{-3}$, error bars omitted), data from Fig. 3a,b

dissolved oxygen was not a factor controlling Mnemiopsis leidyi distributions with concentrations remaining above $4 \mathrm{mg} \mathrm{O}_{2} \mathrm{l}^{-1}$ in surface waters at Stns 1 and 4 .

\section{Comparison between current and historical Mnemiopsis leidyi distributions}

Time-series studies of gelatinous zooplankton in the southern Chesapeake Bay are limited, and Burrell (1972) is the only such study available for the York River estuary. Monthly Mnemiopsis leidyi biovolumes recorded during this (2004-2006) and Burrell's (19681969) study, collected on similar days $( \pm 2)$ of the year and at similar locations (Fig. 1), indicate that present day ctenophore biovolume peaks appear earlier seasonally than $40 \mathrm{yr}$ prior (Fig. 6). In the mesohaline region upriver at Stns 1 and 2, historical (1968-1969) peaks in $M$. leidyi occurred in June and July, and were not observed in May (Fig. 6a). In contrast, during 2004-2006, large ctenophore biovolumes occurred in May upriver (Fig. 6a). Similar trends were observed downriver at Stns 3 and 4 but were offset by about a month, with peaks occurring in July and August during 1968-1969, and in June during 2004-2006 (Fig. 6b).

During 1955-1974, the number of winter-spring days $<10^{\circ} \mathrm{C}$ per year (the minimum temperature for ctenophore reproduction, Purcell et al. 2001) were consistently above the $50 \mathrm{yr}$ mean (i.e. more days $<10^{\circ} \mathrm{C}$, Fig. 7a). However, there was an increase in mean water temperature during the post-1974 period which resulted in significantly fewer days $<10^{\circ} \mathrm{C}$ each winter and spring $(F=14.6, \mathrm{p}<0.001$, Fig. $7 \mathrm{a})$. In addition, there was a significant positive relationship between 

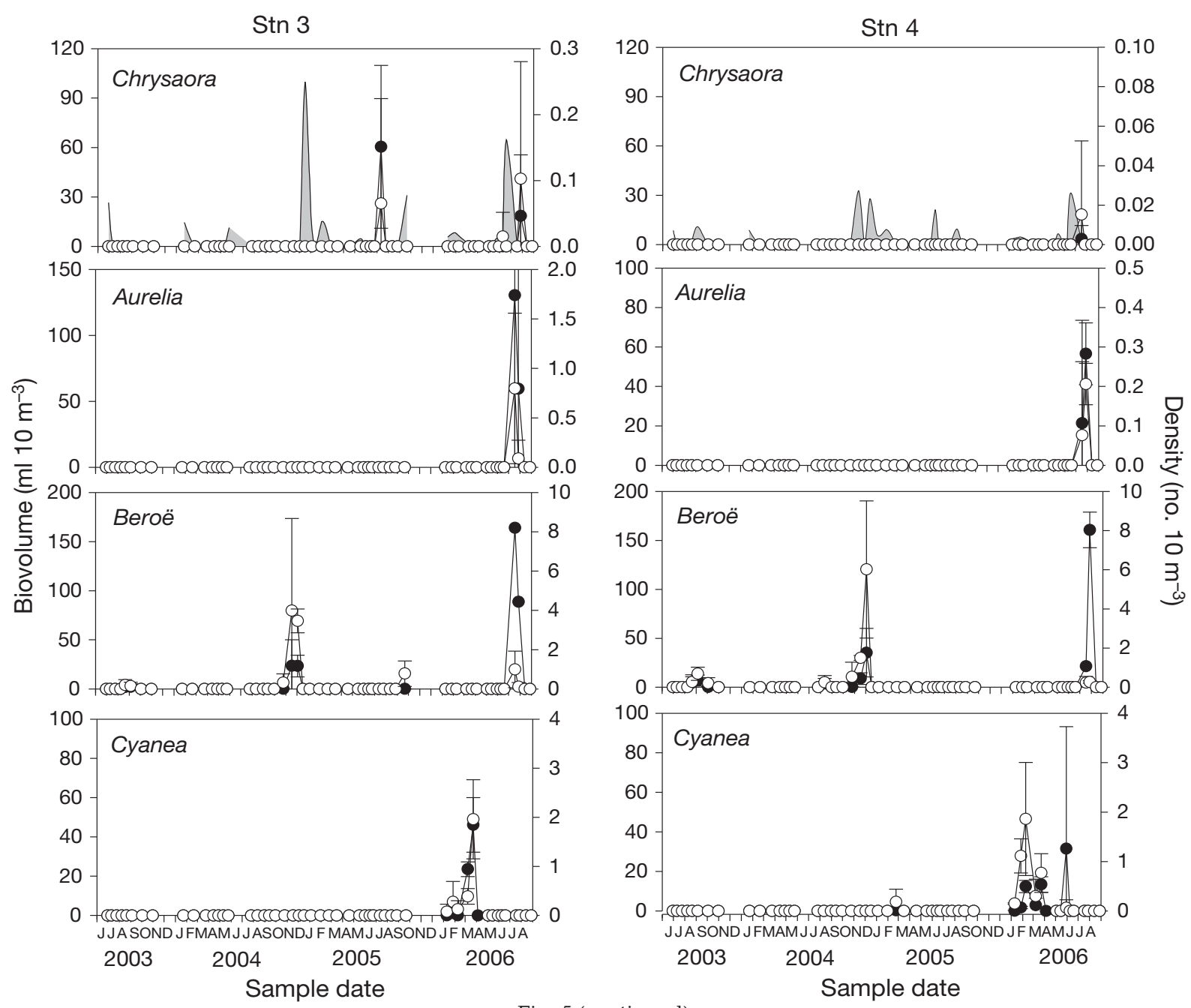

Fig. 5 (continued)

the day of the year in which the temperature reached and remained above the $10^{\circ} \mathrm{C}$ threshold and increases in winter-spring water temperature (linear regression, $\mathrm{r}^{2}=0.47, F=44.8, \mathrm{p}<0.001$, Fig. 7b). There were no significant trends in freshwater discharge from the Pamunkey and Mattaponi Rivers during 1955-2006, suggesting neither flow nor salinity was a driving factor in these shifts.

\section{Food web dynamics and carbon transfer}

\section{Carbon standing stocks}

As there was significantly higher biomass and density of gelatinous zooplankton in the upriver, mesohaline region, we focus our analysis on Stn 1. Water column particulate C:chl a was 80:1 at Stn 1 (Eq. 3, Table 1). Phytoplankton $\mathrm{C}$ biomass was high through- out the year, particularly in the summer (>1000 mg C $\mathrm{m}^{-3}$, Fig. 8a) when annual peaks in chl a were observed in the surface waters. C content in copepod standing stock was generally $<10 \mathrm{mg} \mathrm{C} \mathrm{m}^{-3}$ (Fig. 8b), with some peaks (>60 $\mathrm{mg} \mathrm{C} \mathrm{m}^{-3}$ ) in autumn 2004 and August 2006 when Mnemiopsis leidyi were virtually absent.

C per individual Mnemiopsis leidyi was $1.7 \pm 1.0 \%$ of dry weight. Mnemiopsis C biomass was highest during summer blooms (up to $50.2 \mathrm{mgC} \mathrm{m}^{-3}$ ) and ctenophore $\mathrm{C}$ biomass often exceeded copepod $\mathrm{C}$ biomass at these times (Fig. 8c). Maximum ctenophore densities in winter and spring (except March 2005) contained relatively low carbon biomass $(<2-3 \mathrm{mgC}$ $\mathrm{m}^{-3}$, Fig. 8c). C content in Chrysaora quinquecirrha varied annually and was highest in July when large medusae were present (20-30 $\mathrm{mg} \mathrm{C} \mathrm{m}^{-3}$ ), and directly following ctenophore blooms (Fig. 8d) (See Table 1 for regressions relating $M$. leidyi and $C$. quinquecirrha size to dry weight and C). 


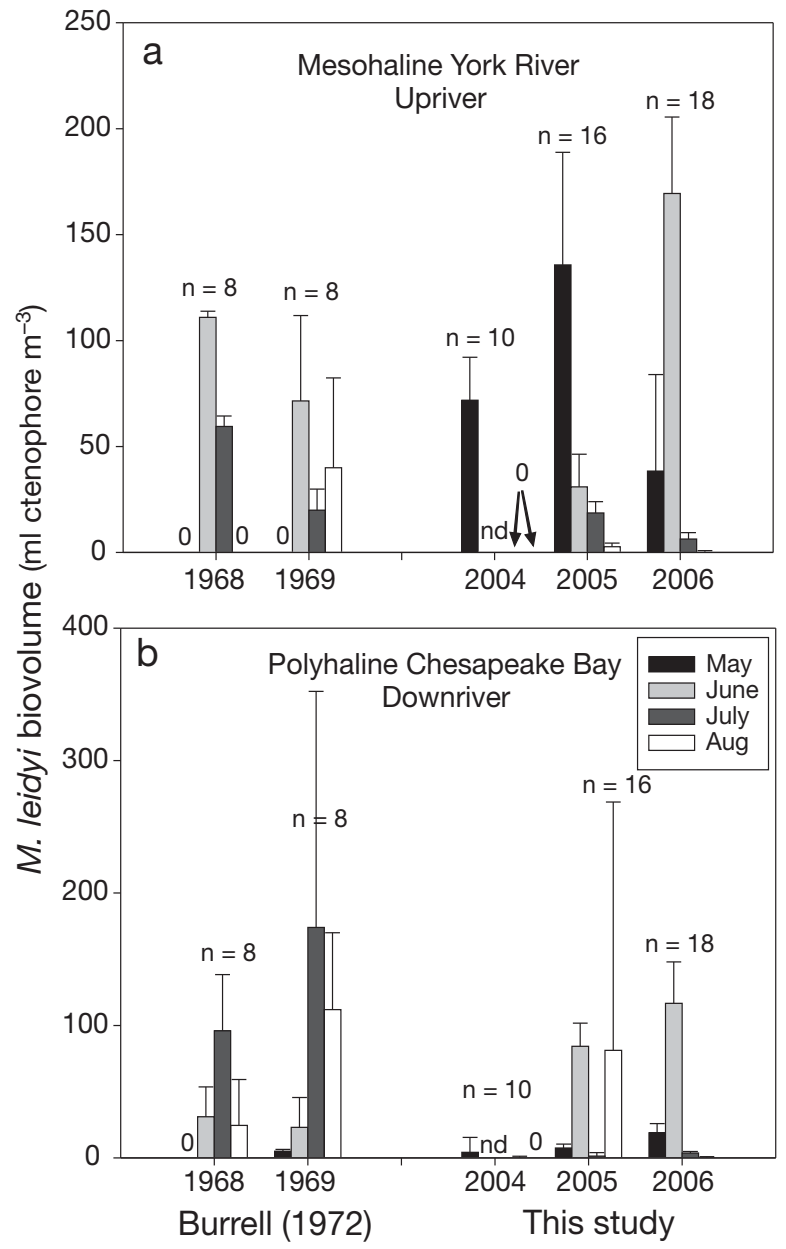

Fig. 6. Mnemiopsis leidyi. Monthly (May-August) comparisons of mean $( \pm \mathrm{SE}) \mathrm{M}$. leidyi biomass (biovolume) between 1968-1969 (Burrell 1972) and 2004-2006 (this study). (a) Upriver, mesohaline region represented by Stns Y10 and Y15 (Burrell 1972) and Stns 1 and 2 (this study). (b) Downriver, polyhaline region represented by Stns CB10 and Y00 (Burrell 1972) and Stns 3 and 4 (this study). See Fig. 1 for station locations. Zeros indicate $M$. leidyi were absent from net collections; nd = no data. Sample size (n) is given for entire May-August period

\section{Carbon transfers between gelatinous zooplankton} and copepods

Predation potential of Chrysaora quinquecirrha on Mnemiopsis leidyi $\left(I_{C q M I}\right)$ was high (consuming $<1-242 \% \mathrm{~d}^{-1}$, and up to $73 \mathrm{mgC} \mathrm{m}^{-3} \mathrm{~d}^{-1}$ of available ctenophore C), but low for copepods $\left(<1-26 \% \mathrm{~d}^{-1}\right.$, $<1 \mathrm{mg} \mathrm{C} \mathrm{m}^{-3} \mathrm{~d}^{-1}$ ) (Table 2). DPP for $M$. leidyi consuming copepods were high $\left(0-208 \% \mathrm{~d}^{-1}\right.$, up to $2.5 \mathrm{mgC}$ $\mathrm{m}^{-3} \mathrm{~d}^{-1}$ ), but were usually lower than medusae consuming lobate ctenophores across sample dates (Table 2).

Mnemiopsis potential population ingestion $\left(I_{M I A C}\right)$ and daily population predation pressure ( $\left.\mathrm{DPP}_{\text {MIAC }}\right)$
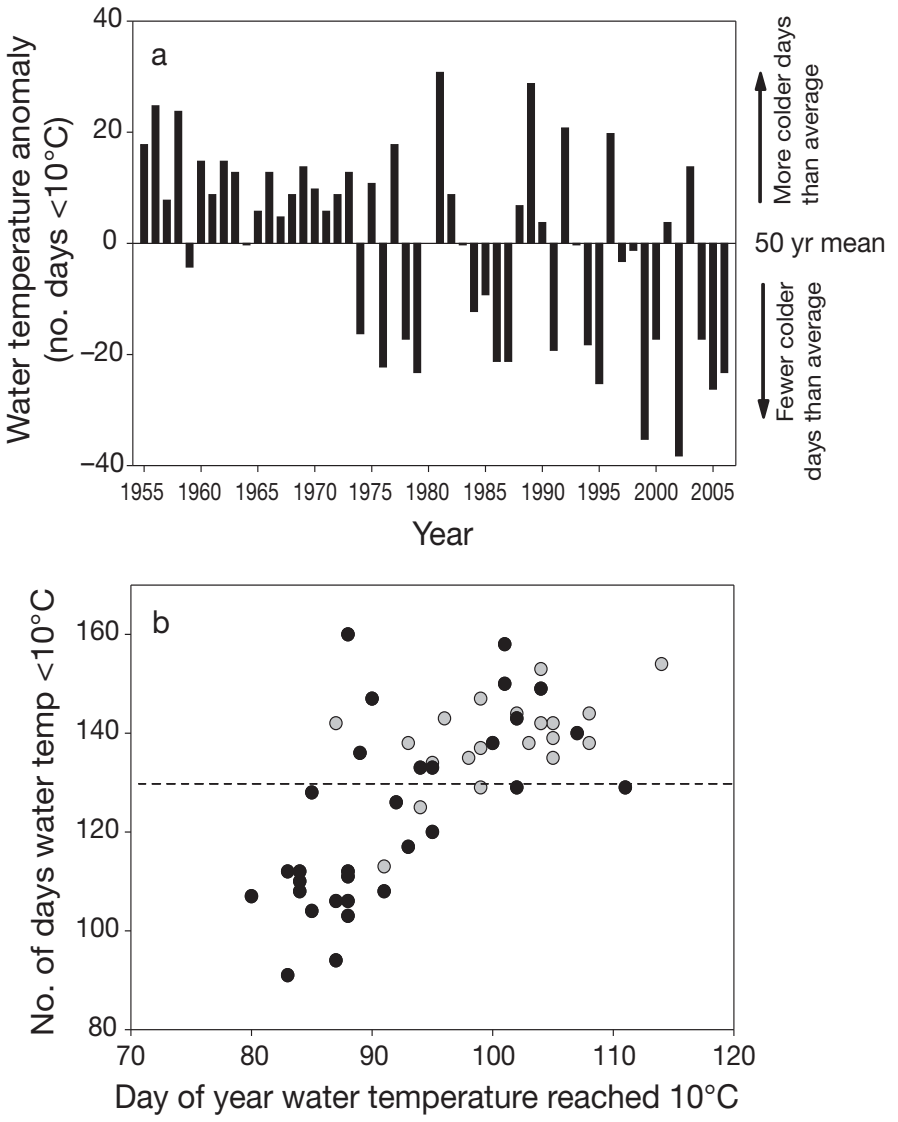

Fig. 7. Increase in water temperature in the York River estuary. (a) Comparison of water temperature anomaly from 1955-2006 against 50 yr mean. York River water temperature anomaly defined as the number of days per year winterspring water temperatures were $<10^{\circ} \mathrm{C}$, minus the $50 \mathrm{yr}$ annual mean (adapted from Austin 2002). Negative anomalies reflect increased water temperatures over the winter-spring period. (b) Water temperature anomaly against day of year when water temperature increased to and remained above $10^{\circ} \mathrm{C}$ threshold ( $x$-axis). Positive, significant linear relationship indicates present day increase in winter-spring water temperatures earlier in the year. (O): 1955-1974; (•): 1975-2006; (---): 50 yr mean of the water temperature anomaly

rates on copepods before $\left(1-21 \% \mathrm{~d}^{-1}, 8-84\right.$ copepods $\mathrm{m}^{-3} \mathrm{~d}^{-1}$ ) and during (typically $0-58 \% \mathrm{~d}^{-1}, 0-697$ copepods $\mathrm{m}^{-3} \mathrm{~d}^{-1}$ ) ctenophore bloom periods were within the range of available standing stocks of copepods (81-1775 copepods $\mathrm{m}^{-3}$, Table 2, Fig. 4). In general, Chrysaora quinquecirrha C-based ingestion rates of M. leidyi $\left(I_{C q M l}\right)$ were initially lower than ctenophore C standing stocks in June (no data for 2004), but were at least an order of magnitude higher than available ctenophore $\mathrm{C}$ in July and August when ctenophore populations were greatly reduced (Table 2, Figs. $3 \& 5$, 8c,d). DPP of C. quinquecirrha consuming copepods $\left(\mathrm{DPP}_{C q A c}\right)$ was low $\left(<20\right.$ copepods $\left.\mathrm{m}^{-3} \mathrm{~d}^{-1}\right)$ throughout 

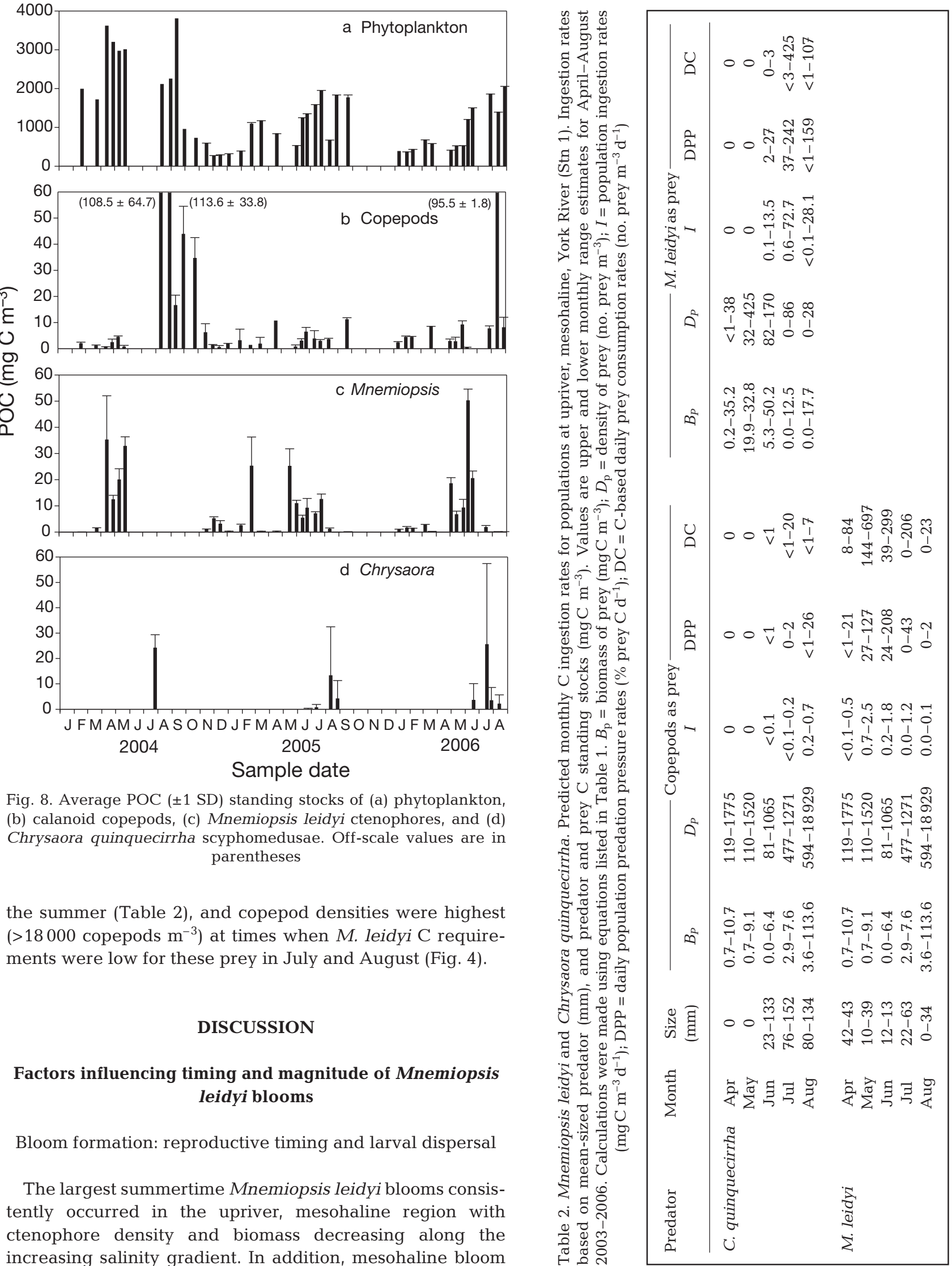

Fig. 8. Average POC $( \pm 1 \mathrm{SD})$ standing stocks of (a) phytoplankton, (b) calanoid copepods, (c) Mnemiopsis leidyi ctenophores, and (d) Chrysaora quinquecirrha scyphomedusae. Off-scale values are in parentheses

the summer (Table 2), and copepod densities were highest (>18000 copepods $\mathrm{m}^{-3}$ ) at times when $M$. leidyi $\mathrm{C}$ requirements were low for these prey in July and August (Fig. 4).

\section{DISCUSSION}

\section{Factors influencing timing and magnitude of Mnemiopsis leidyi blooms}

Bloom formation: reproductive timing and larval dispersal

The largest summertime Mnemiopsis leidyi blooms consistently occurred in the upriver, mesohaline region with ctenophore density and biomass decreasing along the increasing salinity gradient. In addition, mesohaline bloom 
peaks (animals $>10 \mathrm{~mm}$ TL) appeared about 1 mo earlier than those downriver. We attribute this spatial and temporal lag in the accumulation of $M$. leidyi biomass to the reproductive timing and effort associated with seasonal increases in water temperature upriver, coupled to larval dispersal downriver.

Temperature plays an important role in bloom formation because growth, metabolism, maturation, and the initiation of reproduction are thermally dependent (Purcell et al. 2001, Costello et al. 2006). Generally, Mnemiopsis leidyi initiate sexual reproduction when temperatures reach $10^{\circ} \mathrm{C}$, and larger animals $(>30 \mathrm{~mm}$ TL) produce appreciable quantities of eggs at temperatures $>10^{\circ} \mathrm{C}$ (Purcell et al. 2001, Costello et al. 2006). While we did not measure egg production in this study, ctenophore maturity and population reproductive potential were inferred from field densities of potentially mature individuals (>30 $\mathrm{mm}$ TL). Preceding mesohaline ctenophore blooms in April, higher densities of large $M$. leidyi were located upriver at Stn 1 (Fig. 3). As a result, ctenophores may have a greater potential for reproductive output in the mesohaline region, and this process would be accelerated during late spring (April-May) because of removal of temperature limitation on egg production. In turn, high growth rates exhibited by smaller $M$. leidyi at warmer temperatures (Reeve et al. 1989) would contribute to rapid bloom formation in May upriver.

High mesohaline reproductive potentials are supported by cydippid larvae distribution data. Highest larval densities (up to 500 larvae $\mathrm{m}^{-3}$ ) occurred at Stn 1, where larval density peaks co-occurred in space and time with ctenophore bloom peaks, implying that larvae originated locally from blooms in the mesohaline region. In contrast, low densities of larvae $(<100$ larvae $\mathrm{m}^{-3}$ ) occurred downriver at Stn 4, and, while Mnemiopsis leidyi individuals were generally larger at Stn 4, total biomass of potentially reproductively mature ctenophores was low.

Costello et al. (2006) postulated that source-sink characteristics of metapopulation dynamics are an inherent reproductive strategy for maintaining Mnemiopsis leidyi populations worldwide. Metapopulations are localized, subunit populations that originate and are maintained through larval dispersion and recruitment from isolated, reproductive populations (Hanski 1999). We suggest that reproductively active populations of $M$. leidyi in the mesohaline region produce high quantities of larvae which are then transported downriver and seed ctenophore blooms in the polyhaline region. The average residence times for surface water in the lower York River ranges from 25 to $40 \mathrm{~d}$ (Shen \& Haas 2004), and corresponds to observed time lags between summer biomass peaks up- and downriver.
Bloom decline: mortality due to predation, not food limitation

Chrysaora quinquecirrha is a major predator of Mnemiopsis leidyi (Purcell \& Cowan 1995, Purcell \& Decker 2005), and studies have correlated high predation by this gelatinous predator with the bulk removal of ctenophore biomass (Feigenbaum \& Kelly 1984, Purcell \& Decker 2005, Breitburg \& Fulford 2006). The decline in $M$. leidyi blooms in the York River estuary appears to be due primarily to predation by C. quinquecirrha scyphomedusae, and not to bottom-up food limitation of M. leidyi. Chrysaora medusae appeared in surface waters early to mid-summer (June-July) at water temperatures $>25^{\circ} \mathrm{C}$ and salinities ranging from 16 to 20 psu (Decker et al. 2007) (Fig. 6). In conjunction with the arrival of $C$. quinquecirrha, we observed sharp declines in $M$. leidyi biomass, which implies swift removal of ctenophores (2 to 4 wk) by scyphomedusan predators. Predation rates would be highest in the mesohaline region where medusae and ctenophores co-occur and highest densities of both species were consistently recorded. Scyphomedusae C ingestion rates on ctenophores support these conclusions, as predicted daily rations for $C$. quinquecirrha populations typically exceeded prey biomass (Table 2).

In addition, predation pressure by other gelatinous species may accelerate ctenophore depletion in certain years. For example, high densities of large Aurelia medusae, with relatively high predation potentials (e.g. Martinussen \& Bamstedt 1995), were distributed throughout the York River during summer 2006 (Fig. 5). Furthermore, while we did not measure or estimate predation by Beroë, which was occasionally abundant during late summer, Burrell \& van Engel (1976) suggested this cannibal species (not Chrysaora) was responsible for the removal of Mnemiopsis leidyi blooms in the York River. Similar predation effects were observed in the Black Sea following the introduction of Beroë (Kideys 2002, Finenko et al. 2003).

Broad comparisons of predation rates and standing stocks do not incorporate predator and prey growth rates. Mnemiopsis growth (C) rates range from $0.8 \mathrm{~d}^{-1}$ for small ctenophores and $0.34 \mathrm{~d}^{-1}$ for larger ctenophores at prey concentrations comparable to York River densities (Reeve et al. 1989, Purcell et al. 2001). It is improbable that ctenophore growth $\left(<100 \% \mathrm{~d}^{-1}\right)$ could compensate for overall high predation rates by scyphomedusae (up to $240 \% \mathrm{~d}^{-1}$ ). In addition, while growth rates are high, ctenophore blooms upriver comprise smaller-sized individuals that are less efficient at avoiding predation than larger ctenophores (Purcell \& Cowan 1995).

Food limitation is an alternative hypothesis for bloom depletion (Purcell et al. 2001). Copepods are primary 
prey for Mnemiopsis leidyi (Purcell et al. 1994, Purcell \& Decker 2005), and voracious predation by ctenophores can deplete copepod stocks (Purcell \& Decker 2005, Costello et al. 2006). However, in the present study, estimated daily rations for $M$. leidyi on copepods were comparable with copepod standing stocks, and, despite remaining very low in abundance, copepods were not depleted during ctenophore blooms. In addition, ctenophores may be able to reduce resource limitation by supplementing their diet with alternative prey including cladocerans, barnacle nauplii, and microzooplankton (Stoecker et al. 1987, Purcell et al. 1991, Sullivan \& Gifford 2004). We thus conclude that M. leidyi bloom declines in the York River are not a result of food limitation.

Potential role of seasonal refuge for overwintering populations

For blooms to occur annually, mature Mnemiopsis leidyi must develop within or be transported to the regions they occur. Overwintering populations may be important in maintaining $M$. leidyi biomass that will ultimately contribute to bloom formation during the ensuing summer (Costello et al. 2006). In the York River, overwintering populations could adopt several strategies. First, low winter temperatures, while not lethal to Mnemiopsis ctenophores, limit egg production (Purcell et al. 2001, Costello et al. 2006); therefore, blooms could develop directly during non-summer periods within the mesohaline region (Fig. 3). We did observe high winter and spring densities of ctenophores (>400 ind. $\mathrm{m}^{-3}$ ) in some years at Stn 1, which were comprised of small-sized ctenophores that were likely not reproductive at those temperatures. Second, through larval dispersal and recruitment downriver during the previous summer, smaller populations could overwinter, resulting in mature ctenophore transport upriver the following spring. This would be an advantageous survival strategy because of the low densities of scyphomedusae and Beroë, but higher copepod abundances, observed downriver.

Gelatinous zooplankton exhibit unique behavioral adaptations that allow them to utilize certain environmental conditions for movement (Graham et al. 2001, Dawson \& Hamner 2003). We suggest 2 possible physical mechanisms by which ctenophores could be transported upriver. One way would be to use bottom waters of the normal 2-layered estuarine circulation within the tributary (Hayward et al. 1982). Transportation upriver would be dependent on Mnemiopsis leidyi ctenophores actively swimming to depth. In general, larger ctenophores, with presumably higher swimming speeds, were found downriver and would likely be able to adjust their vertical position in the water column (J. Costello pers. comm.). Another potential transport process for ctenophores is tidally based. Haas (1977) demonstrated the breakdown of estuarine circulation during spring tides caused by the intrusion of relatively fresh water from Chesapeake Bay into the York River. Due to the resultant homogeneous conditions, and because the net vertical tidal flux is landward (Haas 1977, Hayward et al. 1982), M. leidyi may use these physical conditions to redirect their distribution upriver.

\section{Influence of climate on Mnemiopsis leidyi blooms}

Comparisons with historical data for Mnemiopsis leidyi in the lower York River suggest that biomass peaks have shifted over the past $40 \mathrm{yr}$. Present day peaks in biomass in the upriver (May) and downriver (June) surface waters appear approximately 1 mo earlier than in the late 1960s (Burrell 1972). The Chesapeake Bay climate and water temperature have undergone major changes during this time frame (Austin 2002), and we hypothesize that shifts observed in $M$. leidyi blooms are associated with these increases in water temperature. Similarly, dramatic 2 mo shifts were observed in M. leidyi blooms of Narragansett Bay, and these were attributed to increases in average monthly surface water temperatures (Sullivan et al. 2001, Costello et al. 2006).

Austin (2002) suggested warmer temperatures can initiate reproductive effort through early spawning of fish larvae. From 1974 to 2006, numbers of consecutive winter and spring days $<10^{\circ} \mathrm{C}$ decreased, and springtime water temperatures reached and remained above $10^{\circ} \mathrm{C}$ approximately 1 mo earlier (Fig. 7). As a result, pre-bloom spawning and larval dispersion by Mnemiopsis leidyi could occur earlier (April), because of release of temperature limitation on egg production. It is unlikely that salinity was a factor in causing changes in $M$. leidyi blooms because there were no trends in freshwater river discharge and lobate ctenophores are euryhaline (Purcell et al. 2001). It is also improbable that ctenophores were flushed at different rates in the Burrell (1972) and present studies because JanuaryJune freshwater river discharge rates from the Pamunkey and Mattaponi Rivers were the same in both sample periods (R. Condon unpubl. data). In addition, scyphomedusae were absent and copepod prey densities were sufficiently high (>10 000 copepods $\mathrm{m}^{-3}$ ) during April and May in the 1960s (Burrell 1972), thus the ctenophore temporal shift is not due to changes in predation pressure or prey limitation.

This early appearance in Mnemiopsis leidyi could also be fostered by decreased predation by Chrysaora 
quinquecirrha, which are absent in April and May. It is unknown whether parallel shifts in the appearance of these gelatinous medusae have occurred, as there are no long-term historical data. Parallel shifts in scyphomedusae would be related to changes in environmental stimuli affecting the timing of asexual reproduction by benthic scyphopolyps (Condon et al. 2001). This is unlikely for $C$. quinquecirrha because salinity and temperature have remained stable during historical periods of asexual reproduction (Austin 2002), and medusae densities may in fact have decreased in northern Chesapeake Bay (Cargo \& King 1990, Breitburg \& Fulford 2006).

Higher winter and spring temperatures may increase the likelihood of blooms of other scyphomedusan species. For example, in spring of 2006 (February-April) high densities of Cyanea sp. medusae were recorded when water temperatures were well above average. During the same time, spring blooms of Mnemiopsis leidyi were not observed. As Cyanea medusae consume lobate ctenophores (Bamstedt et al. 1997), the prevalence of these scyphomedusae with increased temperature may impact winter-spring M. leidyi populations through top-down control, thereby limiting further temporal shifts in ctenophore blooms.

Other studies have recently correlated climatic factors with gelatinous zooplankton populations. In particular, the North Atlantic Oscillation Index (NAO) has been used as an environmental variable to explain increases in medusae (Brodeur et al. 2002, Lynam et al. 2004), including Chesapeake Bay scyphomedusae (Purcell \& Decker 2005). Our limited time-series restricts similar comparisons, although Mnemiopsis leidyi blooms could be connected with NAO as York River water temperature is positively correlated to positive phases of NAO (Austin 2002). While the strength of the positive phase of the NAO has waned in recent years (Austin 2002), anthropogenic influences (e.g. greenhouse gas emissions) may counteract declines in natural climate cycles, forcing temperatures to increase above current levels (Preston 2004). It is unknown how $M$. leidyi blooms will react to future changes in climate for the Chesapeake Bay region.

\section{Consequences of gelatinous zooplankton blooms for carbon cycling}

Increased C assimilation by gelatinous zooplankton linked to temporal bloom shifts

High predation rates by Mnemiopsis leidyi blooms during late spring-summer convert large quantities of $\mathrm{C}$ fixed by primary and secondary producers into gelatinous biomass, which is not consumed by most pelagic organisms. In this regard, gelatinous zooplankton have a potentially negative impact on $\mathrm{C}$ transfer within the planktonic food web by limiting $\mathrm{C}$ bioavailability to higher trophic levels (Berdnikov et al. 1999, Hagy 2002). In estuaries, this shunting of $C$ into gelatinous biomass may have critical costs for fisheries production, especially commercial and anadromous fish that depend on mesozooplankton production for reproduction and growth (Austin 2002, Hagy 2002).

C bioavailability for tertiary production may hinge on the timing of blooms of Chrysaora medusae, and potentially Beroë ctenophores (Burrell \& van Engel 1976, Finenko et al. 2003, Purcell \& Decker 2005) (Table 2). For example, Purcell \& Decker (2005) noted that when C. quinquecirrha predominated, Mnemiopsis leidyi biomass was suppressed, releasing top-down control on copepods. However, as M. leidyi blooms have shifted earlier seasonally, the transformation of copepod $\mathrm{C}$ into gelatinous form would now also occur 1 mo earlier. Furthermore, declines in $M$. leidyi by $C$. quinquecirrha predation occurs mid-summer, when a large amount of copepod C standing stock has already been consumed and converted into gelatinous biomass. Thus, temporal shifts in M. leidyi bloom peaks may simply prolong the residence time in which $\mathrm{C}$ is 'locked up' in gelatinous form.

C transfer within the summertime York River planktonic food web probably culminates with Chrysaora quinquecirrha. However, temporal shifts in Mnemiopsis leidyi blooms in the York River estuary may in turn limit C. quinquecirrha medusae populations. Following rapid declines of $M$. leidyi in June, estimated $C$ requirements for $C$. quinquecirrha consuming $M$. lei$d y i$ were much greater than available in ctenophore standing stocks. Based on these estimates, we suggest the rapid decline in $C$. quinquecirrha scyphomedusae is the result of C-limitation. This hypothesis is supported by stable isotope data with elevated $\delta^{15} \mathrm{~N}$ values in Chrysaora medusae related to periods of starvation in summer (Hagy 2002). At these times, Beroë sp. may be important alternative prey for C. quinquecirrha, although Beroë sp. may also become C-limited due to bulk $M$. leidyi removal.

\section{Potential fate of C assimilated by gelatinous zoo- plankton blooms}

We suggest the potential enhancement of two $\mathrm{C}$ pathways associated with ctenophore and scyphomedusae blooms. First, live gelatinous zooplankton could accelerate regeneration of assimilated $\mathrm{C}$ as dissolved inorganic and organic $C$ via respiration, excretion, and mucus production (Kremer 1977, Hansson \& Norrman 1995). This process may be prominent during starva- 
tion when scyphomedusae can survive on stored C reserves (Hamner \& Jenssen 1974). In turn, recycling of gelatinous zooplankton metabolites could augment the summertime dominance of bacterioplankton by fueling their metabolism (Hansson \& Norrman 1995). Second, moribund gelatinous zooplankton could sink from surface waters and ultimately contribute to benthic production (Billett et al. 2006). While phytoplankton cells generally contribute the majority of the annual $\mathrm{C}$ export from surface waters in Chesapeake Bay (Kemp et al. 2005), gelatinous zooplankton could enhance summertime C flux (Billett et al. 2006) because carcasses may penetrate strong vertical stratification barriers that exist throughout the estuary during summer (Haas 1977, Hayward et al. 1982). All of these suggested pathways of $C$ transfer, in conjunction with temporal shifts and worldwide spatial increases in gelatinous zooplankton blooms, indicate gelatinous species have the potential to significantly alter $\mathrm{C}$ availability and transfer within planktonic food webs.

Acknowledgements. This study was supported in part by grants from the National Science Foundation (OCE 0221825) to D.K.S., D. Bronk, and W. Smith, and the National Oceanic and Atmospheric Administration (NA04NOS4780265) to M. Decker, R. Hood, C. Brown, T. Gross and J. Purcell. We thank K. Moore for help with the CBNERRSVA database, J. Cope, B. Lawson, E. Condon, S. Goldthwait, S. Tozzi, D. Wilcox, J. Dreyer, and H. Nees for field and laboratory assistance. We also gratefully acknowledge the comments of E. Condon, T. Bouvier, J. Costello, M. Brush, D. Bronk, M. Graham, H. Ducklow, K. Tang, and 2 anonymous reviewers which improved the manuscript.

\section{LITERATURE CITED}

Austin HM (2002) Decadal oscillations and regime shifts, a characterization of the Chesapeake Bay marine climate. Am Fish Soc Symp 32:155-170

Bamstedt U, Ishii H, Martinussen MB (1997) Is the scyphomedusa Cyanea capillata (L.) dependent on gelatinous prey for its early development? Sarsia 82:269-273

Berdnikov SV, Selyutin VV, Vasilchenko VV, Caddy JF (1999) Trophodynamic model of the Black and Azov Sea pelagic ecosystem: consequences of the comb jelly, Mnemiopsis leiydi, invasion. Fish Res 42:261-289

Billett DSM, Bett BJ, Jacobs CL, Rouse IP, Wigham BD (2006) Mass deposition of jellyfish in the deep Arabian Sea. Limnol Oceanogr 51:2077-2083

Breitburg DL, Fulford RS (2006) Oyster-sea nettle interdependence and altered control within the Chesapeake Bay ecosystem. Estuar Coast 29:776-784

Brodeur RD, Sugisaki H, Hunt GL Jr (2002) Increases in jellyfish biomass in the Bering Sea: implications for the ecosystem. Mar Ecol Prog Ser 233:89-103

Burrell VG (1972) Distribution and abundance of calanoid copepods in the York River estuary, Virginia, 1968 and 1969. PhD dissertation, Virginia Institute of Marine Science, College of William \& Mary

Burrell VG, van Engel WA (1976) Predation by and distribution of a ctenophore, Mnemiopsis leidyi A. Agassiz, in the York River estuary. Estuar Coast Shelf Sci 4:235-242
Cargo DG, King DR (1990) Forecasting the abundance of the sea nettle, Chrysaora quinquecirrha, in the Chesapeake Bay. Estuaries 13:486-491

> Condon RH, Decker MB, Purcell JE (2001) Effects of low dissolved oxygen on survival and asexual reproduction of scyphozoan polyps (Chrysaora quinquecirrha). Hydrobiologia 451:89-95

Costello JH, Sullivan BK, Gifford DJ, Van Keuren D, Sullivan LJ (2006) Seasonal refugia, shoreward thermal amplification and metapopulation dynamics of the ctenophore Mnemiopsis leidyi in Narragansett Bay, Rhode Island. Limnol Oceanogr 51:1819-1831

Dawson MN, Hamner WM (2003) Geographic variation and behavioral evolution in marine plankton: the case of Mastigias (Scyphozoa, Rhizostomeae). Mar Biol 143: 1161-1174

Decker MB, Breitburg DL, Purcell JE (2004) Effects of low dissolved oxygen on zooplankton predation by the ctenophore Mnemiopsis leidyi. Mar Ecol Prog Ser 280: 163-172

- Decker MB, Brown CW, Hood RR, Purcell JE and others (2007) Predicting the distribution of the scyphomedusa Chrysaora quinquecirrha in Chesapeake Bay. Mar Ecol Prog Ser 329:99-113

Faasse MA, Bayha KM (2006) The ctenophore Mnemiopsis leidyi A. Agassiz 1865 in coastal waters of the Netherlands: an unrecognized invasion? Aquat Invasions 1: $270-277$

- Feigenbaum D, Kelly M (1984) Changes in the lower Chesapeake Bay food chain in presence of the sea nettle Chrysaora quinquecirrha (Scyphomedusae). Mar Ecol Prog Ser 19:39-47

Finenko GA, Romanova ZA, Abolmasova GI, Anninsky BE and others (2003) Population dynamics, ingestion, growth and reproduction rates of the invader Beroe ovata and its impact on plankton community in Sevastopol Bay, the Black Sea. J Plankton Res 25:539-549

> Graham WM, Pages F, Hamner WM (2001) A physical context for gelatinous zooplankton aggregations: a review. Hydrobiologia 451:199-212

> Haas LW (1977) The effect of the spring-neap tidal cycle on the vertical salinity structure of the James, York and Rappahannock rivers, Virginia, USA. Estuar Coast Mar Sci 5: $485-496$

Hagy JD (2002) Eutrophication, hypoxia and trophic transfer efficiency in Chesapeake Bay. PhD dissertation, University of Maryland, College Park, MD

Hamner WM, Jenssen RM (1974) Growth, degrowth, and irreversible cell differentiation in Aurelia aurita. Am Zool 14: 833-849

Hanski I (1999) Metapopulation ecology. Oxford University Press, New York

Hansson LJ, Norrman B (1995) Release of dissolved organic carbon (DOC) by the scyhozoan jellyfish Aurelia aurita and its potential influence on the production of planktic bacteria. Mar Biol 121:527-532

> Hayward D, Welch CS, Haas LW (1982) York River destratification: an estuary-subestuary interaction. Science 216: $1413-1414$

Hsieh BB (1979) Variation and prediction of water temperature in York River estuary at Gloucester Point, Virginia. MS thesis, Virginia Institute of Marine Science, College of William \& Mary

$>$ Kemp WM, Boynton WR, Adolf JE, Boesch DF and others (2005) Eutrophication of Chesapeake Bay: historical trends and ecological interactions. Mar Ecol Prog Ser 303: $1-29$ 
Kideys AE (2002) Enhanced: fall and rise of the Black Sea ecosystem. Science 297:1482-1484

Kremer P (1977) Respiration and excretion by the ctenophore Mnemiopsis leidyi. Mar Biol 44:43-50

Lin J, Kuo AY (2001) Secondary turbidity maximum in a partially mixed microtidal estuary. Estuaries 24:707-720

Link JS, Ford MD (2006) Widespread and persistent increase of Ctenophora in the continental shelf ecosystem off NE USA. Mar Ecol Prog Ser 320:153-159

Lynam CP, Hay SJ, Brierley AS (2004) Interannual variability in abundance of North Sea jellyfish and links to the North Atlantic Oscillation. Limnol Oceanogr 49:637-643

Martinussen MB, Bamstedt U (1995) Diet, estimated daily food ration and predator impact by the scyphozoan jellyfishes Aurelia aurita and Cyanea capillata. In: Skjoldal HR, Hopkins C, Erikstad KE, Leinaas HP (eds) Ecology of fjords and coastal waters. Elsevier, Amsterdam, p 127-145

Mills CE (2001) Jellyfish blooms: Are populations increasing globally in response to changing ocean conditions? Hydrobiologia 451:55-68

Murdy EO, Birdsong RS, Musick JA (1997) Fishes of Chesapeake Bay. Smithsonian Institution Press, Washington, DC

> Nemazie DA, Purcell JE, Glibert PM (1993) Ammonium excretion by gelatinous zooplankton and their contribution to the ammonium requirements of microplankton in Chesapeake Bay. Mar Biol 116:451-458

Preston BL (2004) Observed winter warming of the Chesapeake Bay estuary (1949-2002): implications for ecosystem management. Environ Manage 34:125-139

Purcell JE (1988) Quantification of Mnemiopsis leidyi (Ctenophora, Lobata) from formalin-preserved plankton samples. Mar Ecol Prog Ser 45:197-200

Purcell JE (1992) Effects of predation by the scyphomedusan Chrysaora quinquecirrha on zooplankton populations in Chesapeake Bay, USA. Mar Ecol Prog Ser 87:65-76

Purcell JE, Cowan JH Jr (1995) Predation by the scyphomedusan Chrysaora quinquecirrha on Mnemiopsis leidyi ctenophores. Mar Ecol Prog Ser 129:63-70

Purcell JE, Decker MB (2005) Effects of climate on relative predation by scyphomedusae and ctenophores on copepods in

Editorial responsibility: Peter Verity,

Savannah, Georgia, USA
Chesapeake Bay during 1987-2000. Limnol Oceanogr 50: 376-387

Purcell JE, Cresswell FP, Cargo DG, Kennedy VS (1991) Differential ingestion and digestion of bivalve larvae by the scyphozoan Chrysaora quinquecirrha and the Mnemiopsis leidyi. Biol Bull (Woods Hole) 180:103-111

Purcell JE, White JR, Roman MR (1994) Predation by gelatinous zooplankton and resource limitation as potential controls of Acartia tonsa copepod populations in Chesapeake Bay. Limnol Oceanogr 39:263-278

Purcell JE, Shiganova TA, Decker MB, Houde ED (2001) The ctenophore Mnemiopsis in native and exotic habitats: U.S. estuaries versus the Black Sea basin. Hydrobiologia 451:145-176

Quinn GP, Keough MJ (2002) Experimental design and data analysis for biologists. Cambridge University Press, New York

- Reeve MR, Syms MA, Kremer P (1989) Growth dynamics of a ctenophore (Mnemiopsis) in relation to variable food supply. I. Carbon biomass, feeding, egg production, growth and assimilation efficiency. J Plankton Res 11:535-552

> Roman MR (1977) Feeding of the copepod Acartia tonsa on the diatom Nitzschia closterium and brown algae (Fucus vesiculosus) detritus. Mar Biol 42:149-155

Shen J, Haas LW (2004) Calculating age and residence time in the tidal York River using three-dimensional model experiments. Estuar Coast Shelf Sci 61:449-461

Stoecker DK, Verity PG, Michaels AE, Davis LH (1987) Feeding by larval and post-larval ctenophores on microzooplankton. J Plankton Res 9:667-683

Sullivan LJ, Gifford DJ (2004) Diet of the larval ctenophore Mnemiopsis leidyi A. Agassiz (Ctenophora, Lobata). J Plankton Res 26:417-431

Sullivan BL, van Keuren D, Clancy M (2001) Timing and size of blooms of the ctenophore Mnemiopsis leidyi in relation to temperature in Narragansett Bay, RI. Hydrobiologia 451:113-120

Uye SI, Fujii N, Takeoka H (2003) Unusual aggregations of the scyphomedusa Aurelia aurita in coastal waters along western Shikoku, Japan. Plankton Biol Ecol 50:17-21

Submitted: October 5, 2007; Accepted: May 30, 2008

Proofs received from author(s): October 4, 2008 